\title{
An Initial Experiment on the Effects of Digital Transformation and Technological Entrepreneurship in Organizational Performance
}

\author{
Uma Gunasilan, Norshahrizan Nordin, Tunku Salha Bt Tunku Ahmad, Julinawati Suanda
}

\begin{abstract}
Digital transformation of entrepreneurship and innovation has the potential to have an impact on policymakers and major stakeholders, thus positively influencing organizations at both regional and national level. Digital transformation and technology entrepreneurship has also influenced government-based agencies and public institutions to reframe and restructure their policies, laws and regulations with relation to numerous public, social, regional and national issues which tend to have a direct impact on the performance of the organizations and corporate sectors established in the regions, namely Malaysia, Singapore and Thailand. Technological entrepreneurship, in the present scenario, has a direct association with digital transformation adopted in an organization and its overall performance. Thus, this research attempts to explore the impact and the role of technological entrepreneurship on the extent is has in enhancing the performance of an organization and its adoption of digital transformation in various sectors within the organization.
\end{abstract}

Keywords: digitalization, digital transformation technological entrepreneurship, technopreneurship.

\section{INTRODUCTION}

Digitalization results in a significant growth and development of the organization with enhanced performance. The main concern of this research is to determine the influence of entrepreneurship in digital transformation. The research will attempt to shed light on the current issue of digital transformation. The objective of this research is to study the different variables that affect digital transformation and technological entrepreneurship in organizational performance in an organization. Previously, there are many studies, which had been carried out on several different variables on this study, however the relationship between the digital transformation and technological entrepreneurship towards organizational performance especially with moderators such

Revised Manuscript Received on March, 282020.

* Correspondence Author

Uma Gunasilan*, School of Business and Technopreneurship, Universiti Malaysia Perlis (UniMAP), Perlis, Malaysia,

Norshahrizan Nordin, Senior Lecturer, School of Business and Technopreneurship, Universiti Malaysia Perlis (UniMAP), Perlis, Malaysia

Tunku Salha bt Tunku Ahmad, School of Business and Technopreneurship, Universiti Malaysia Perlis (UniMAP), Perlis, Malaysia

Julinawati bt Suanda, School of Business and Technopreneurship, Universiti Malaysia Perlis (UniMAP), Perlis, Malaysia

(C) The Authors. Published by Blue Eyes Intelligence Engineering and Sciences Publication (BEIESP). This is an open access article under the CC BY-NC-ND license (http://creativecommons.org/licenses/by-nc-nd/4.0/) as complexity and dynamism have not been studied. Through this research, we have identified the three major factors that play a role in determining interdependencies of an organization's performance based on digital transformation and technological entrepreneurship. In its entirety, the research studies the impact of technological entrepreneurship and digital transformation on organizational performance.

Thus, this study focuses on the role and impact on the performance of organizations on adopting digital transformation and technological entrepreneurship. The research primarily emphasizes on the South Asian countries, namely, Malaysia, Thailand, and Singapore to study the digital transformation and organizational performance of technological entrepreneurship.

\section{LITERATURE REVIEW}

\section{A. Nature of Work}

Various sectors including manufacturing sector, banking sector, healthcare, and telecommunication are impacted by digital transformation. Digital transformation assists the organizations in improving the innovation practices of the firms, creating enhanced designs and preparing new business models. In addition to this, the digital transformation has transformed how the values are created by the organizations on the internet. With the help of effective digital transformation strategies, firms can enhance their relationships with the customers and escalate the cross selling opportunities. Digital transformation is not just about acquiring and using new technologies. It plays a significant role in helping the firms to tackle various problems related to business procedure redesign, human resources and business efficiency. Therefore, it is important to understand the concept of digital transformation.

\section{B. Digital Transformation}

Many firms worldwide are trying to increase their competitive advantage by adopting digital transformation. However, the gap between the intentions of the entrepreneurs and successful digital transformation initiatives are still wide. This study has adopted systematic review to gather information for the research. The findings of the study have revealed that companies adopt digital transformation mainly to overcome the decrease in sales and financial constraints.

Published By:

Blue Eyes Intelligence Engineering

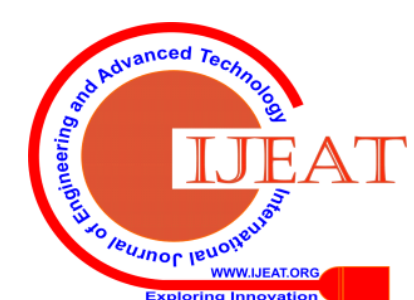


In addition to this, employees prefer to work in companies that are digitally strong and have IT power. The results of the study have suggested that reprogram ability, and self-referential nature of make digital transformation a better choice.

[1] Research explored the options that are available for developing a digital transformation strategy. At present, due to the advancements in the technology, many firms are facing many challenges related to the formulation of a digital transformation strategy. This study is being conducted to help such firms. From the above-discussed studies, the phenomenon of digital transformation is understood clearly. The studies have indicated that digital transformation cannot be adopted successfully without the expertise in technology and experience in the process of digitalization. Digital transformation is adopted by the firms mainly to overcome the crunch in resources, decrease in sales and financial constraints and gain competitive advantage in the industry they operate. Further, digital transformation makes the firms attractive to the employees as they want to work in firms that are digitally supported and have IT facilities rather than firms that use traditional mechanisms. Furthermore, most of the studies related to digital transformation have only concentrated on the various issues in the firms that force the firms to adopt digital transformation. However, only a countable number of studies have concentrated on the various aspects of digital transformations that are important for the firms to adopt an appropriate digital transformation strategy for the study.

\section{Technological Entrepreneurship}

Entrepreneurs who distinguish their organizations' situations in the aggressive system of the business accurately reinforce and connect with circumstances and eradicate the adverse ramifications of dangers and shortcomings, thus getting higher performance [3]. Along these lines, organizations that foundation technological entrepreneurship as a procedure that penetrates and spreads all through the whole association will, in general, accomplish positive outcomes after some time in the feeling of improved inside efficiencies, higher worker resolve and real upgrades in performance.

For technological organizations, different current investigations demonstrate a positive connection between corporate entrepreneurship and organizational performance [3]; [4] demonstrate that positive financial performance in the field of high-tech or information and communication technology organizations rely upon entrepreneurship capital, the limit of an area to help entrepreneurs. Then again, organizations may permit the utilization of their technology to different organizations inside the business, in this way making new business and improving their income and benefits. In this way, technological opportunities in an industry are related decidedly with expanded Technological Entrepreneurship [3], factors having an impact on technological entrepreneurship are identified and listed below;

a. Sustainability- Environmental sustainability refers to resource efficiency and the capacity of the environment to endure human manipulation.

b. Social awareness- Social environmental awareness is derived from education, which takes place within society, to raise awareness of the effects of environmental damage and environmental education.

c. Policies and environmental regulation- Policies include institutional and organizational initiatives designed to promote entrepreneurship. Environmental regulations on the other hand, ensure compliance with the pertinent legislation.

\section{Organizational Performance}

[5] conducted research to identify the factors that influence and affect organizational performance. It is indicated that the environmental factor that has a significant impact on the performance of an organization is Supply Chain Management. It has been considered to direct singular correspondences inside an organization and to be a basic predecessor factor for the achievement of learning the executives' initiatives and an indicator of organizational performance. [4] classified supply chain management examination into three classes:

a. an operational methodology that identifies with generation, stock, and operational instruments;

b. a structure approach that manages operational frameworks and data and

c. a key methodology that alludes to connections and upper hand.

[5] Utilized data sharing and innovative association to quantify the degree of combination in the production network. Okongwu et al investigated the connection between supply chain management practices and organizational performance. They quantified Supply Chain Management rehearses as far as data sharing, provider associations, client connections, and data quality

\section{E. Internal Cohesiveness}

Generally, the concept of organizational performance is conceived on the basis of the notion that an organization is a combination of assets including capital, human and physical resources which are productive and helps to attain a common goal. The organizational performance is enhanced by a variety of aspects including the moderating factors including complexity and dynamism interacts with digital transformations and technological entrepreneurships to influence the performance of the organizations. Complexity, in this context, refers to the extent to which the activities of an organization are dispersed. Dynamism refers to the extent to which an organization can experience instability and the turbulence caused by various factors.

Further, to determine the role of technological entrepreneurship as a driver of digital transformation in enhancing the organizational performance specifically in Malaysia, Singapore and Thailand and to evaluate the impact of technological entrepreneurial strategy and internal cohesiveness on organizational performance and cost strategy of organizations based in Malaysia, Singapore and Thailand, the following theoretical framework has been adopted for the study.

Published By:

Blue Eyes Intelligence Engineering

$\&$ Sciences Publication

(C) Copyright: All rights reserved. 
TABLE I PROPOSED CONCEPTUAL FRAMEWORK

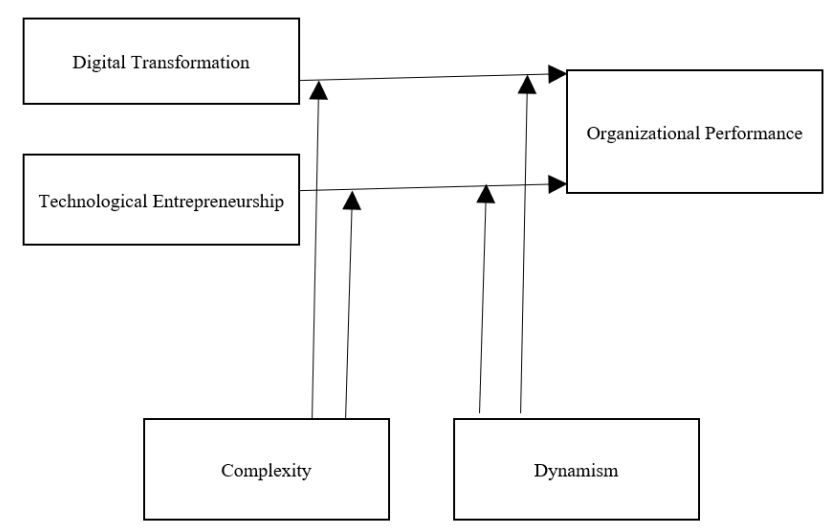

\section{METHODOLOGY AND DERIVATION}

This study adopted a systematic review to gather information for the research. This study would attempt to follow the descriptive design or quantitative design because of its advantage over explanatory which is the overlook to perceive the occurrence in an entirely natural environment [2].

From the review of previous studies and theories, it is clear that many studies have concentrated on the impact of digital transformation on performance of the firms [3] and impact of technological entrepreneurship on the performance of the [4] and [5] separately.

\section{A. Research Techniques}

In this design, the data is gathered over a period of time repeatedly for same subject [6]. This type of research design basically provides direction and it mainly focuses on the relationship that is informal [7]. Generally, longitudinal studies have a tenancy to acquire more resources. Also, longitudinal resources are costlier than cross-sectional resources. [8].

\section{B. Sampling Techniques}

Quantitative analysis can be preceded by selecting a simple random method. This method will cross verify and guarantee that the eligibility requirements are met. The simple random sampling involves data being selected randomly through computer within a formulated sampling frame. Though this method is simple and easy to use, this method tends to have large sampling errors and less precision data [9]. Further, in this method of stratified random sampling, the data is categorized into several sub groups called strata with common characteristics of the sample such as age, gender, income, education level and ethnicity from which sample is selected randomly. Moreover, for collecting the data, the present research adopts simple systematic random sampling method.

This study first focuses on refining the firms based on the size of the firms. Since digital transformation affects more among large and mid-size firm, this study aims to focus on larger companies. This study will choose list of large firms from Thailand, Singapore and Malaysia and arrange it according to their annual turnover. Further, the first company is randomly selected and then every $3^{\text {rd }}$ or $5^{\text {th }}$ company is chosen and the questionnaire is sent through email for conducting the survey. The email ids of the chosen companies are taken from the company website and request for conducting the survey among the four officers in the respective companies is sent. If the company responds within a week, the conducting of survey will be continued, else the $4^{\text {th }}$ or $6^{\text {th }}$ company will be chosen from the sample size and the survey is continued. Based on the responses, the sample size considered in the study is 27 .

\section{Sampling Size}

The target area chosen for this study is Malaysia [10], Singapore and Thailand. The 2018 GEI [11], professional body as well as reports from World Bank 2018 justifies choosing these three countries.

The research is often concerned with the individuals who are selected from the whole population. As a pilot test, questionnaires were distributed to approximately 30 companies, an average of 10 top IT companies each in Malaysia, Singapore and Thailand. The companies were identified through the 2018 GEI report with justification.

\section{Population}

These three countries are emerging in terms of technopreneurship and hence considered for this study. [12] The target population of the study is Chief Operation Manager, Chief Information Officer, IT managers, and operational managers who represent different departments (HR, Marketing, and Production) of the organization in Thailand, Singapore, and Malaysia.

This study does not include product development managers, as the roles and responsibilities of product development managers have similarities with Chief Operation Manager and Chief Information Officers who were already included in the study.

\section{E. Data Collection}

In this research, a questionnaire-based survey method is used for primary data collection to determine the impact of digital transformation and technological entrepreneurship in enhancing organizational performance. This information forms the foundation for the questionnaire development in order to collect the primary data in a numerical form as table below.

TABLE II QUESTIONNAIRE DESIGN STRUCTURE

\begin{tabular}{lll}
\hline Sections & Section contains & $\begin{array}{l}\text { Questions } \\
\text { contained }\end{array}$ \\
\hline A & Demographic details & 5 \\
\hline B & Digital transformation & 16 \\
\hline C & Technological entrepreneurship & 19 \\
\hline D & Internal Cohesiveness (Dynamism and & 7 \\
\hline E & Complexity) & 7 \\
\hline
\end{tabular}

Since the current study adopts questionnaire as the tool for data collection it is important to provide a well-structured questionnaire as it is significantly important for the success of the current study. The questionnaire is sent to chief operation manager, chief information officer, IT managers, chief marketing officer, business development manager, and operational managers who can represent different department (HR, Marketing, and Production) of the organizations in Malaysia,

Published By:

Blue Eyes Intelligence Engineering

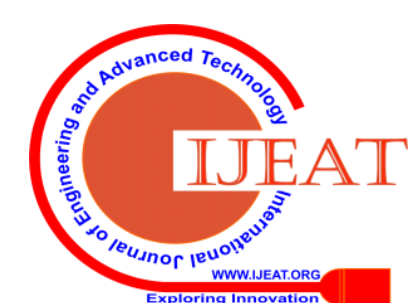


Thailand and Singapore respectively. Moreover, upon sending the questionnaire to the respondents, this study provides necessary sufficient instructions for answering the questions within the stipulated amount of time. The purpose of conducting the survey is clearly explained to the respondents and a panel of experts in the field reviews the survey content.

\section{F. Data Analysis}

The data that was gathered through the questionnaires were analyzed using Statistical Package for Social Science (SPSS). Correlation analysis is used to understand the relationship between the elements of digital transformation and technological entrepreneurship in organizational performance. The data collected from the questionnaire is analyzed in the form of descriptive analysis. Descriptive statistics is a method of presenting the results of research conducted in the form of a simple statistical popular which are mean, standard deviation, Pearson and correlation. Other than that, Cronbach's Alpha, validity and reliability is going to be tested in this pilot research.

\section{RESULTS AND FINDINGS}

\section{A. Demographic Background of Respondents}

The questionnaire was developed in a manner that avoids the bias in the data that was collected from the participants of the research. Further, relevant steps were in this study to ensure the anonymity and confidentiality of the data gathered from the respondents. This was done to avoid biased data [13] and the results are shown as in the table below.

\section{TABLE III RESULTS OF DESCRIPTIVE ANALYSIS}

\section{B. Validity Test}

It is necessary to evaluate the internal relatedness before a test for ensuring validity of the research [14]. Then the questionnaire can be modified with the help of the results acquired from the pilot study. The pilot study is responsible for ensuring the reliability of the questionnaire [15]. The pre testing and piloting was conducted in order to enhance the quality and reliability of the questionnaire. Based on the responses from the pilot study, reliability analysis is conducted to evaluate the quality of the test instrument. From the pilot study, it can be understood that regular follow up of the questionnaires is required to ensure a proper response from the participants and the results of the pilot study ensures reliability of the test instrument [16]. Thus, the reliability analysis is conducted in this study in order to determine the instrument degree of reliable and error-free. In the pilot test, the reliability test, Cronbach's Alpha test was conducted in order to determine the reliability. The data was categorized according to the item statistics. As long as the value of Cronbach's Alpha is above 0.7, all items can be deemed reliable as shown in the Table below.
TABLE IV RESULTS OF RELIABILITY TEST

\begin{tabular}{|l|l|l|l|}
\hline Variables & $\begin{array}{l}\text { Num of } \\
\text { items }\end{array}$ & $\begin{array}{l}\text { Cronbach's } \\
\text { Alpha }\end{array}$ & Status \\
\hline $\begin{array}{l}\text { Digital } \\
\text { transformation (IV) }\end{array}$ & 16 & 0.896 & Good \\
\hline $\begin{array}{l}\text { Technological } \\
\text { entrepreneurship } \\
\text { (IV) }\end{array}$ & 19 & 0.889 & Good \\
\hline $\begin{array}{l}\text { Internal } \\
\text { cohesiveness (MV) }\end{array}$ & 7 & 0.785 & \begin{tabular}{l} 
Acceptabl \\
\hline $\begin{array}{l}\text { Organizational } \\
\text { performance (DV) }\end{array}$
\end{tabular} \\
\hline
\end{tabular}

Based on the result above, we can see that the Cronbach's Alpha for Digital Transformation is 0.896, Technological Entrepreneurship is 0.889, Internal Cohesiveness is 0.785 and Organizational Performance is 0.857. All the results of Cronbach's Alpha for each variable are either greater than 0.700 or greater than 0.800 which are consider as acceptable and good. Thus, the results for all the variables are reliable which consider acceptable and good for the study.

\section{Correlation Analysis}

Based on [16], Pearson product-moment correlation coefficient was conducted in this study. The strength and direction of association between two variables are measured by Pearson correlation coefficient. The two variables must be measured on a continuous (interval) scale. The correlation coefficient (r) ranges from -1 to 1 .

From the table representing the results below, the factors digital transformation $(\mathrm{r}=0.613, \mathrm{p}<0.01)$, technological entrepreneurship ( $\mathrm{r}=0.727, \mathrm{p}<0.01)$ and internal cohesiveness

\begin{tabular}{|c|c|c|c|}
\hline Variables & Categories & Frequency & $\begin{array}{l}\text { Percentage } \\
(\%)\end{array}$ \\
\hline \multirow{2}{*}{ Gender } & Male & 20 & 74.1 \\
\hline & Female & 7 & 25.9 \\
\hline \multirow{3}{*}{ Age } & $\begin{array}{l}\text { Below } 35 \\
\text { years }\end{array}$ & 4 & 14.8 \\
\hline & $35-45$ years & 20 & 74.1 \\
\hline & $46-55$ years & 3 & 11.1 \\
\hline \multirow{3}{*}{ Education } & Graduate & 3 & 11.1 \\
\hline & $\begin{array}{l}\text { Post } \\
\text { Graduate }\end{array}$ & 23 & 85.2 \\
\hline & $\mathrm{PhD}$ & 1 & 3.7 \\
\hline \multirow{4}{*}{ Designation } & IT Manager & 10 & 37.0 \\
\hline & $\begin{array}{l}\text { Operational } \\
\text { Manager }\end{array}$ & 6 & 22.2 \\
\hline & $\begin{array}{l}\text { Chief } \\
\text { Operational } \\
\text { Manager }\end{array}$ & 4 & 14.8 \\
\hline & $\begin{array}{l}\text { Chief IT } \\
\text { Manager }\end{array}$ & 7 & 25.9 \\
\hline \multirow{4}{*}{ Experience } & $\begin{array}{l}\text { Less than } 10 \\
\text { years }\end{array}$ & 7 & 25.9 \\
\hline & $11-15$ years & 13 & 48.1 \\
\hline & $16-20$ years & 4 & 14.8 \\
\hline & $\begin{array}{l}\text { Above } 20 \\
\text { years }\end{array}$ & 3 & 11.1 \\
\hline Total & & 27 & 100.0 \\
\hline
\end{tabular}

Published By:

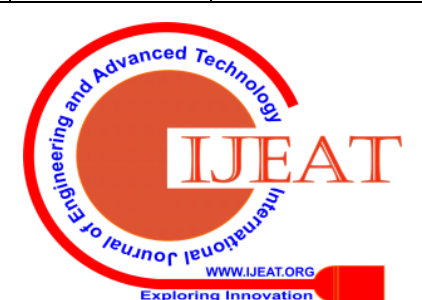


( $r=0.705, \mathrm{p}<0.01$ ) were strong positively relationship with organizational performance.

TABLE VRESULTS OF CORRELATION ANALYSIS

\begin{tabular}{|c|c|c|c|}
\hline Variables & & $\begin{array}{l}\text { Organizational } \\
\text { Performance }\end{array}$ & $\mathbf{N}$ \\
\hline \multirow{3}{*}{$\begin{array}{l}\text { Digital } \\
\text { transformation }\end{array}$} & $\begin{array}{l}\text { Pearson } \\
\text { Correlation }\end{array}$ & $0.613^{* *}$ & \multirow{3}{*}{7} \\
\hline & $\begin{array}{l}\text { Sig. } \\
\text { (2-tailed) }\end{array}$ & 0.000 & \\
\hline & Status & $\begin{array}{l}\text { Strong } \\
\text { (positive) }\end{array}$ & \\
\hline \multirow{3}{*}{$\begin{array}{l}\text { Technological } \\
\text { Entrepreneurship }\end{array}$} & $\begin{array}{l}\text { Pearson } \\
\text { Correlation }\end{array}$ & $0.727 * *$ & \multirow{3}{*}{27} \\
\hline & $\begin{array}{l}\text { Sig. } \\
\text { (2-tailed) }\end{array}$ & 0.000 & \\
\hline & Status & $\begin{array}{l}\text { Strong } \\
\text { (positive) }\end{array}$ & \\
\hline \multirow{3}{*}{$\begin{array}{l}\text { Internal } \\
\text { Cohesiveness }\end{array}$} & $\begin{array}{l}\text { Pearson } \\
\text { Correlation }\end{array}$ & $0.705^{* *}$ & \multirow{3}{*}{27} \\
\hline & $\begin{array}{l}\text { Sig. } \\
\text { (2-tailed) }\end{array}$ & 0.000 & \\
\hline & Status & $\begin{array}{l}\text { Strong } \\
\text { (positive) }\end{array}$ & \\
\hline
\end{tabular}

\section{CONCLUSION}

From the analysis that has been performed, it looks likely positive that the correlation between the three variables proposed in the framework, i.e. digital transformation, technological entrepreneurship and internal cohesiveness all have a very strong positive impact on organizational performance as seen in Table $\mathrm{V}$ above. This result allows for this study to now move to its second phase of exploring quantitatively the positive significant impacts between digital transformation and organizational performance, technological entrepreneurship and organizational performance as well as the positive significant impact of internal cohesiveness on the dependent variables towards the independent variable as referred to in Table I earlier.

The continuance of this study's aim is also to venture into the possibilities of looking into the three countries that have been identified, i.e. Malaysia, Singapore and Thailand and the variance that the organizations in these countries provide upon the investigation in detail of the above.

\section{REFERENCES}

1. Hess, T., Matt, C., Benlian, A., \& Wiesböck, F. (2016). Options for Formulating a Digital Transformation Strategy. MIS Quarterly Executive, 15(2), 123-139. Retrieved from https://www.researchgate.net/publication/291349362_Options_for_For mulating_a_Digital_Transformation_Strategy

2. Ethridge, D. E. (2004). Research Methodology in Applied Economics. Wiley.

3. Njoroge, Ongeti, Kinuu, \& Kasomi. (2016). Does External Environment Influence Organizational Performance? The Case of Kenyan State Corporations. Management and Organizational Studies, 3(3). https://doi.org/10.5430/mos.v3n3p41.

4. García-Sánchez, E., García-Morales, V., \& Martín-Rojas, R. (2018). Influence of Technological Assets on Organizational Performance through Absorptive Capacity, Organizational Innovation and Internal $\begin{array}{llll}\text { Labour } & \text { Flexibility. } & \text { Sustainability, } & \text { 10(3), }\end{array}$ https://doi.org/10.3390/su10030770

5. Garrido-Moreno, A., Martín-Rojas, R., González-Alvarez, N., \& García-Morales, V. J. (2014). The use of Technology to improve Organizational Performance through Corporate Entrepreneurship-. Retrieved September 30, 2019, from https://www.researchgate.net/publication/278003856_The_use_of_Tech nology_to_improve_Organizational_Performance_through_Corporate_E ntrepreneurshipR. Nicole, "Title of paper with only first word capitalized," J. Name Stand. Abbrev., in press.

6. Pettigrew, A. M. (1990). Longitudinal Field Research on Change: Theory and Practice. Organization Science, 1(3), 267-292

7. UKEssays. (2018). Research Methodology: Cross Sectional Research Design

8. Levin, K. A. (2006). Study design III: Cross-sectional studies. Evidence-Based Dentistry, 7(1), 24-25. https://doi.org/10.1038/sj.ebd.6400375

9. Acharya, A. S., Prakash, A., Saxena, P., \& Nigam, A. (2013). Sampling: why and how of it? Indian Journal of Medical Specialities, 4(2) https://doi.org/10.7713/ijms.2013.0032

10. Editorial, Im. (2014). Raising Technopreneurs In Malaysia. Retrieved from iMoney website: https://www.imoney.my/articles/raising-technopreneurs-in-malaysia

11. Herrington, M., \& Kew, P. (2016). Global Entrepreneurship Monitor 2016/2017. Global Entrepreneurship Monitor, 1-180. https://doi.org/10.1017/CBO9781107415324.004

12. Friedrich-Naumann-Stiftung. (n.d.). 3 Factors Contributing to the Rise of Southeast Asian Entrepreneurs and Startups. Retrieved from Friedrich-Naumann-Stiftung für die Freiheit website: https://asia.fnst.org/content/3-factors-contributing-rise-southeast-asian-e ntrepreneurs-and-startups

13. Saunders, M., Lewis, P., \& Thornhill, A. (2000). Research methods for business students (2nd ed.). Retrieved from https://books.google.co.in/books/about/Research_Methods_for_Busine ss_Students.html?id=FjVEAAAAYAAJ\&redir_esc $=y$

14. Tavakol, M., \& Dennick, R. (2011). Making sense of Cronbach's alpha. International Journal of Medical Education, 2, 53-55. https://doi.org/10.5116/ijme.4dfb.8dfd

15. Saunders, M., Lewis, P., \& Thornhill, A. (2003). Research Methods for Business Students (3rd ed.) [Book]. Retrieved from https://www.worldcat.org/title/research-methods-for-business-students/ oclc/50280078

16. Frazer, L., \& Lawley, M. (2000). Questionnaire Design \& Administration: A Practical Guide. Retrieved from https://books.google.co.in/books?id=GnZgQgAACAAJ

\section{AUTHORS PROFILE}

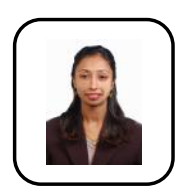

Uma Gunasilan* is an Associate Professor in the field of Computer Information Systems and Management. Uma holds a $\mathrm{PhD}$ in her field of Computer Science from University of Northumbria, U.K, a MSc from University Putra Malaysia and a BSc from University Science Malaysia. In the past 10 years, Uma has published in various journals and conference papers on subjects varied across the interdiciplines of Distributed Networking, Information Systems Management and the current research interest which is Entrepreneurship and Technopreneurship. She has also been an active academic for the past 20 years practicing in South East Asia, Middle East, Australia, Ireland and U.K. Uma is also a Fellow of the Higher Education Academy, U.K.

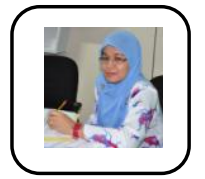

Norshahrizan Nordin is an Senior Lecturer in the school of Business Innovation and Technopreneurship, Universiti Malaysia Perlis (UniMAP). She has obtained a $\mathrm{PhD}$ in Operational Research, from University Malaysia Kelantan in Malaysia. Her MSc was in Information \& Communication Technology, University Utara Malaysia, and her Bachelor of Technology Management was also from University Utara Malaysia. Prior to this, she obtained her Diploma in Manufacturing Technology, KUSZA (Kolej Ugama Sultan Zainal Abidin) also in Malaysia. Her specialization includes; Operational Research, Kano Model, Quality Function Deployment (QFD), Service Quality.

Published By:

Blue Eyes Intelligence Engineering

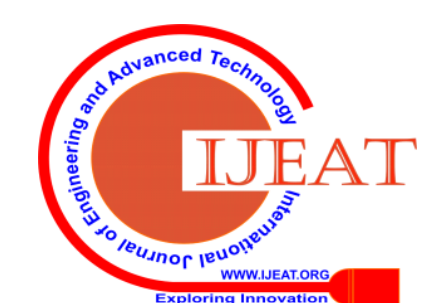


Similarly, her research interests are Healthcare Management, Prioritization, Service Delivery, Nonlinear Algorithm, Service Engineering, Kansei Engineering, Customer Satisfaction and Dissatisfaction, Analytical Hierarchical Process (AHP), Product Design, Manufacturing Technology, Technology Management, Industrial Technology.

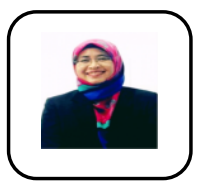

Tunku Salha bt Tunku Ahmad is an Associate Professor in the school of Business Innovation and Technopreneurship, Universiti Malaysia Perlis (UniMAP). She is also currently the Director of the Centre for International Affairs, in Universiti Malaysia Perlis. Tunku holds a Doctor of Philosophy in Health Economics from Athlone Institute of Technology, in Ireland, a Master of Economics from Universiti Utara Malaysia, a Bachelor of Economics (Hons) also from Universiti Utara Malaysia. Prior to this, she obtained her Diploma of Education, from the Regional Centre for Education in Science and Mathematics(RECSAM) in Penang, Malaysia. Her specializations are in particular in Health Economics. Her research interests include Health Economics and Human Development.

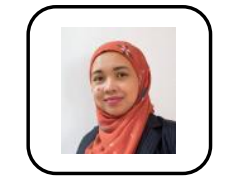

Julinawati Suanda $(\mathrm{PhD})$ is a Senior Lecturer at the School of Business Innovation and Technopreneurship, Universiti Malaysia Perlis (UniMAP). She is also the Deputy Dean (Student and Alumni Development) in her faculty. She holds a Bachelor Degree (Hons) in Public Management (Universiti Utara Malaysia), Master of Business Administration (Universiti Utara Malaysia), and Doctoral Degree in Health Marketing (Athlone Institute of Technology, Ireland). She is experienced in the field of Marketing and Business. Her doctoral degree focused in Health Marketing in which she applied two kinds of research methodologies in Qualitative and Quantitative. She is experienced in teaching and learning for 11 years' expertise in Marketing and Management. She also involved in research activities with 3 grants secured as co-researchers. She has published numbers of publications and participated in few conferences as presenter. She also participated in poster presentations in local and international exhibitions. She was also invited as Jury for local exhibitions. As for community services, she has involved as a consultant for the development of local lake by getting the social responses. Other than the above, last but not least she also contributed as one of the writers for entrepreneurial book published and looking forward for a new publication this year. 